\title{
Morphological and Physiological Changes during Maturation of New Mexican Type Peppers
}

\author{
Charles Lee Biles, Marisa M. Wall' ${ }^{1}$ and Kevin Blackstone \\ Department of Entomology, Plant Pathology and Weed Science, New Mexico State University, Las Cruces, \\ NM 88003
}

\begin{abstract}
Additional index words. B-galactosidase. ethylene. Capsicum annuит, respiration, postharvest
Abstract. New Mexican Chile peppers ( Capsicum annuum L. 'New Mexico 6-4') were harvested at weekly intervals beginning 20 days after flowering (DAF), and were evaluated for ethylene $\left(\mathrm{C}_{2} \mathrm{H}_{4}\right)$ production, respiration rates, chlorophyll content, degradative enzyme activity (cellulase, polygalacturonase, B-galactosidase), and fruit firmness. Morphological and physiological changes were most apparent in peppers harvested 54 to 69 DAF. B-galactosidase activity increased rapidly beginning 54 DAF and reached a peak by 89 DAF. Fruit firmness was highest (36 newtons) at 54 DAF and had decreased significantly by 69 DAF. Carbon dioxide production and chlorophyll content were highest in young pods harvested $20 \mathrm{DAF}$ and decreased steadily thereafter. A climacteric increase of $\mathrm{CO}$, was absent. There were two peaks in $\mathrm{C}_{2} \mathrm{H}_{4}$ production: one associated with rapid fruit growth and the other with color change (61 to $69 \mathrm{DAF}$ ). Fruit harvested on the same day but at different developmental stages (green to red) were similar to those observed in fruit harvested over the season for the physiological characteristics tested. Separation of pepper fruit soluble proteins on SDS-PAGE demonstrated increased intensity in protein bands at 27,35 , and $40 \mathrm{kDa}$ and decreased intensity of $51 \mathrm{kDa}$ band as the fruit matured. Several biochemical processes appeared to be enhanced in Chile pepper fruit from 47 to $69 \mathrm{DAF}$.
\end{abstract}

The New Mexican type pepper 'New Mexico 6-4' is an integral part of the unique culture of the southwestern United States. In New Mexico, this pepper type is commonly called Chile. Chile peppers are either pungent or nonpungent, green or red, 15 to $18 \mathrm{~cm}$ long, and $\approx 5 \mathrm{~cm}$ wide (Bosland et al., 1988). When harvested green, New Mexican Chile peppers are eaten fresh, canned, or frozen. If allowed to mature on the plant, the peppers turn red and eventually dehydrate. Dried red Chile fruit are ground into Chile powder or paprika.

The growth and lengthening of green Chile pods follows a single sigmoidal curve, similar to the growth pattern for bell pepper fruit (Miller et al., 1979; Pety and Cotter, 1984). No studies have investigated the physiological changes that occur during the maturation and ripening of Chile peppers. Whereas bell peppers are generally classified as nonclimacteric fruits (Lurie et al., 1986; Miller et al., 1979; Salveit, 1977), Korean hot pepper types have been reported aseitherclimacteric for C. annuum L. 'Chooraehong' (Grosset al., 1986). or nonclimacteric for C. annuum L. 'Changjiao' (Lu et al., 1990). Nonclimacteric fruit do not show the dramatic rise in respiration and ethylene production during ripening that is commonly observed with climacteric fruit (Biale, 1964). The ripening behavior of New Mexican type peppers, with respect to respiration and ethylene production rates, is unknown.

Ripening-related changes in cell wall composition have been documented for many fruit species. In a survey of 17 fruit types, hot peppers had the greatest net loss $(56 \%)$ of noncellulosic neutral sugars from the cell walls during ripening. Galactose was the major residue lost (Gross and Sams, 1984). B-galactosidase activity increased, whereas polygalacturonase (PG) activity was undetected. Our objectives were to determine the maturation and ripening related changes in New Mexican type peppers. Variables mea-

Received for publication 10 Apr. 1992. Accepted for publication 3 Nov. 1992. This research was supported by the New Mexico Agriculture Experiment Station. We thank Heather Stoltzfus, Gaye Faubion. Julie Baca, and Deena Baca for their excellent technical support. The cost of publishing this paper was defrayed in part by the payment of page charges. Under postal regulations, this paper therefore must be hereby marked advertisement solely to indicate this fact.

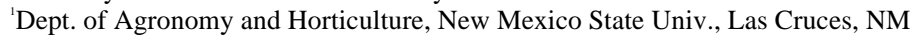
88003. sured were polygalacturonase (E.C. 3.2.1.15), cellulase (E.C. 3.2.1.4), and B-galactosidase (E.C. 3.2.1.23) activities, CO, and $\mathrm{C}_{2} \mathrm{H}_{4}$ production rates, chlorophyll content, and fruit firmness.

\section{Materials and Methods}

Plant material. 'New Mexico 6-4' peppers were planted on 1 May 1991, in a field plot south of Las Cruces, N.M. The plots were cultivated and maintained according to local practices. Flowers were tagged at anthesis (24 July 1991). and pepper fruit were harvested weekly beginning 13 Aug. 1991. In addition, pepper fruit at developmental stages from immature green to red were harvested from plants on 11, 18, and 25 Sept., and physiological characteristics were measured.

Ethylene and $\mathrm{CO}_{2} \cdot \mathrm{C}_{2} \mathrm{H}_{4}$ and $\mathrm{CO}_{2}$ were measured weekly. Four replications with three pods per replication were used for each measurement. Volume and weight were determined for each fruit. Volume was determined by submerging the fruit in water and measuring displacement. Fruit were placed in 2-liter, gas-tight jars with a rubber septum in the lid to allow gas sample withdrawal. Mean fruit weight varied from $\approx 20$ to $60 \mathrm{~g}$, depending on developmental stage (Fig. 1). Average time from harvest to sealing of the jars was $\approx 1 \mathrm{~h}$. Jars were kept at room temperature under fluorescent room lights.

Samples $(1 \mathrm{ml})$ were withdrawn at hourly intervals for $8 \mathrm{~h}$. Percentage of $\mathrm{CO}_{2}$ was determined using an infrared gas analyzer (Illinois Instruments, McHenry, Ill.) calibrated with a $1.0 \% \mathrm{CO}_{2}$ standard.

Ethylene production was determined with a Hewlett Packard 5840A gas chromatograph equipped with an alumina column and flame ionization detector. Samples $(1.0 \mathrm{ml})$ were collected $24 \mathrm{~h}$ after sealing the jars. A gas standard containing $10.5 \mathrm{nl} \mathrm{C}_{2} \mathrm{H}_{4} /$ liter was used for calibration.

Firmness analysis. The force required to puncture the chile fruit was measured in three locations on the fruit: near the stem end, center, and tip of the pod. Firmness measurements for the three

Abbreviations: DAF, days after flowering; $\mathrm{C}_{2} \mathrm{H}_{4}$, ethylene; SDS-PAGE, sodium dodecyl sulfate-polyacrylamide gel electrophoresis; DNS. dinitrosalicylic acid. 
locations were averaged to obtain a value for each fruit. Three fruit were tested from each of four replications. The firmness tests were performed with a Wagner (Wagner Instruments, Greenwich, Conn.) Force Dial model FDN 100 with a $6.5-\mathrm{mm}$ probe, and the values recorded in newtons.

Chlorophyll assay. The chile fruit used for firmness measurements were also used to measure for chlorophyll. Six pairs of $8-\mathrm{mm}$ disks were cut from adjacent sides of each chile to be as similar in weight as possible. Disk pairs were cut from the top, middle, and bottom of each chile. One side (top, middle, and bottom) of the disks was used to determine milligrams of chlorophyll per gram fresh weight, and the other disks were used to determine milligrams of chlorophyll per gram dry weight. Chlorophyll content was determined with a spectrophotometer (Abeles et al., 1989).

Fruit color. Chile fruit at four stages of ripeness were harvested 18 Sept. 1991, and divided into five replications of four pods each. Maturity stages were characterized according to fruit color. Peppers in the green $(\mathrm{G})$ ripeness group were fully developed pods, showing no orange or red pigmentation, and considered ready for green pepper harvest. Peppers developed to this stage by 30 to 40 days after flowering (DAF). The green/red (G/R) group was $10 \%$ to $20 \%$ orange or red, whereas the red/green $(\mathrm{R} / \mathrm{G})$ group was $50 \%$ to $60 \%$ orange or red. Color development began $\approx 47$ to $54 \mathrm{DAF}$. The fourth group contained chile fruit that were completely red (R). In 1991, fruit were completely red by 68 DAF. Visual color was quantified using a Minolta CE-200 Chromameter (Minolta, Ramsey, N.J.) reading in the L,a,b mode. The $\mathrm{L}$ values express the lightness or darkness of colors, with lighter colors having higher L values. The $\mathrm{a}: \mathrm{b}$ ratio represents the green to red (a) color range divided by the blue to yellow range (b). Samples with high $a / b$ values are reddest. Color was measured in four locations to obtain an accurate representation. These measurements were repeated on chile fruit harvested 1 week later (25 Sept. 1991).

Enzyme extraction and gel electrophoresis. Pepper fruit were stored at $-40 \mathrm{C}$ until used for enzyme assays. Acetone powders were prepared from pepper fruit as described by Abeles and Biles (1990). In brief, $10 \mathrm{~g}$ of frozen pepper tissue were homogenized in $\approx 30 \mathrm{ml}$ of acetone at room temperature. The homogenate was filtered through Whatman \#1 filter paper on a Buchner funnel and washed with acetone at least three times. The powder was air dried at room temperature and stored at $-20 \mathrm{C}$. Protein was extracted with distilled deionized water (24C) for proteins used in gel electrophoresis or $0.05 \mathrm{M}$ acetate buffer $(\mathrm{pH} 5)$ for enzyme assays. The buffer and acetone powder paste (10 buffer : 1 powder) was passed through miracloth (Chicopee Mills, N.Y.), and the extract was centrifuged for $5 \mathrm{~min}$ at $15,000 \times \mathrm{g}$. Extracts used for gel electrophoresis were filtered through a $0.22-\mu \mathrm{m}$ filter after centrifugation. Proteins were concentrated through addition of $100 \mu \mathrm{l}$ of $100 \%$ trichloroacetic acid (TCA) to $900 \mu \mathrm{l}$ of extract. The precipitated proteins were washed once in TCA and twice in $100 \%$ acetone. Precipitated proteins with loading buffer were heated for $3 \mathrm{~min}$ at 100C. Total protein $(4 \mu \mathrm{g} / \mathrm{lane})$ was separated on $4 \%$ stacking and $12 \%$ separation SDS-PAGE slab gels $(0.75 \mathrm{~mm}$ thick) using the Laemmil (1970) buffer system, according to the instructions provided by BioRad (Richmond, Calif.). Gels were electrophoresed with $200 \mathrm{~V}$ (constant voltage) until the bromophenol tracking dye front moved off the gel and stained with colloidal coomassie brilliant blue G-250, according to Neuhoff et al. (1988). BioRad low molecular weight protein standards were used to estimate protein size. Protein (of pepper extracts) was measured with the BioRad protein dye method.

B-galactosidase activity was determined according to Gross et al. (1986). The substrate $(450 \mu \mathrm{l}$ of $1 \%$ p-nitrophenyl B-D- galactopyranoside, $15 \mathrm{~mm} \mathrm{NaCl}, 0.06 \%$ bovine serum albumin (w/ v) in $50 \mathrm{~mm} \mathrm{Na}$-acetate, $\mathrm{pH} 5.0$ ) was incubated with $50 \mu \mathrm{l}$ of enzyme extract for $1 \mathrm{~h}$. The reaction was stopped by adding $1 \mathrm{ml}$ of $0.2 \mathrm{M} \mathrm{Na}_{2} \mathrm{CO}_{3}$, and released p-nitrophenyl groups were measured with a spectrophotometer at $400 \mathrm{~nm}$. The standards contained p-nitrophenyl, and controls had $0.2 \mathrm{M} \mathrm{Na}_{2} \mathrm{CO}_{3}$ added at time 0 . Polygalacturonase activity was determined by placing a $100-\mu \mathrm{l}$ aliquot of acetone powder extract in $900 \mu 1$ of $1 \%$ polygalacturonic acid in a $0.05-\mathrm{M}$ acetate buffer at $\mathrm{pH} 5$ and incubating the tubes at $30 \mathrm{C}$ for $24 \mathrm{~h}$. Dinitrosalicylic acid reagent (DNS) (200 pl) was added to the enzyme and substrate and heated at $100 \mathrm{C}$ for $5 \mathrm{~min}$ (Miller, 1959). Reducing groups were determined with a spectrophotometer at $500 \mathrm{~nm}$. Cellulase activity was measured in a similar way, except the substrate was $1 \%$ carboxymethyl cellulose (medium viscosity) in $0.05 \mathrm{~m}$ acetate buffer, $\mathrm{pH}$ 5. Each treatment (harvest date or color group) consisted of three replications, and the experiments were conducted three times within the same harvest.

Statistical analyses were performed with the Statistical Analysis System (SAS Institute, Cary, N.C.). Data were subjected to oneway analyses of variance, and treatment means were compared with Fisher's protected least significant difference (LSD) test.

\section{Results}

Chile peppers increased in fresh weight and volume from 20 to 33 DAF (Fig. 1), and fresh weight and volume significantly decreased in fruit harvested later in the season (89 DAF). Fruit wall firmness increased steadily from $24 \mathrm{~N}$ at $20 \mathrm{DAF}$ to $36 \mathrm{~N}$ at $54 \mathrm{DAF}$ (Fig. 2), then declined to $8 \mathrm{~N}$ on the last harvest date (103 DAF).

Chlorophyll content followed similar trends in fresh and dry weight samples (Fig. 3). The chlorophyll content decreased significantly from 20 to $33 \mathrm{DAF}$ and then maintained the same level for $\approx 4$ weeks. By $60 \mathrm{DAF}$, chlorophyll content had decreased significantly. At this time, pepper fruit were beginning to show orange and red pigmentation (breaker/turning stage). Green and red fruit harvested on the same day also showed significant differences in chlorophyll content (Table 1). The loss of chloro-

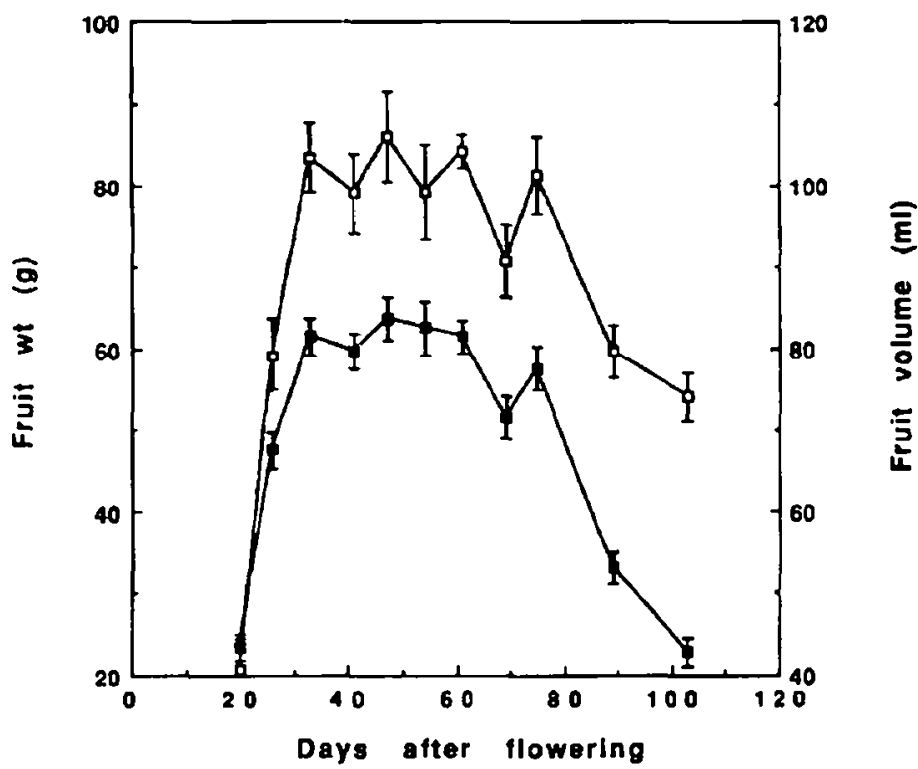

Fig. 1. Fruit weight ( $(\mathbb{)}$ ) and volume (U) of New Mexican type peppers harvested weekly. Each point represents the mean of measurements taken from 12 fruit at each harvest date. Error bars represent the SE of the mean. $1 . S D_{(0.0)}$, values for fruit weight and volume were 6.5 and 12.0 , respectively. 


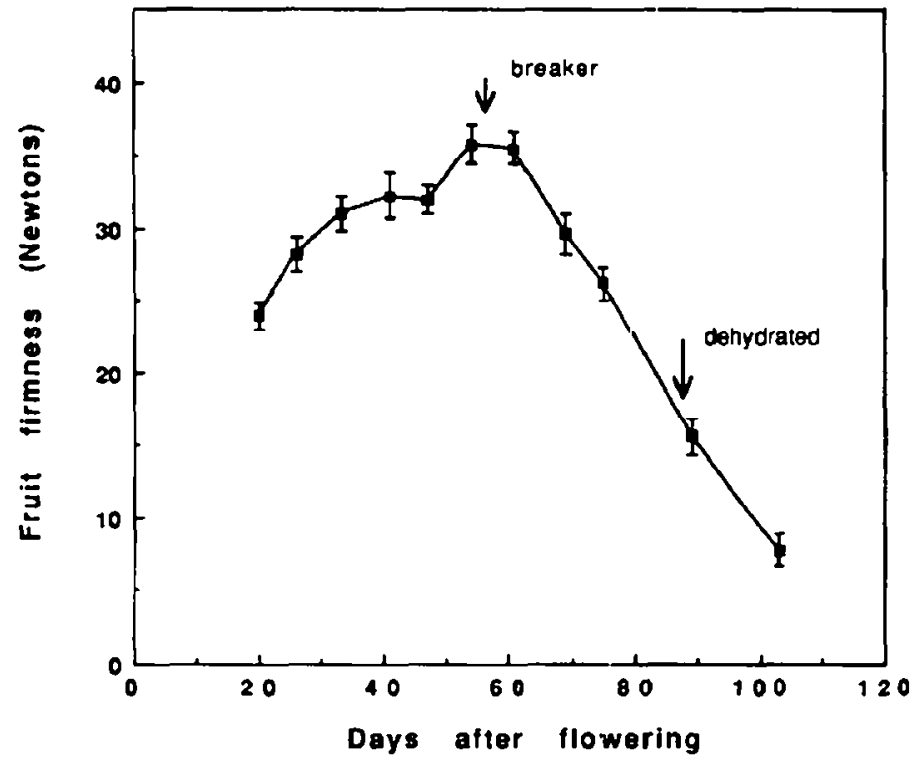

Fig. 2. Fruit firmness for New Mexican type chile harvested at weekly intervals throughout the season. Arrows indicate the approximate start of color change from green to red (breaker) and when $25 \%$ of the fruit was near dehydration on the plant. Twelve fruit were tested at each harvest date with three measurements taken on each fruit. Error bars represent the SE of the: mean. The $\mathrm{LSO}_{100}$, value was 3.4 .

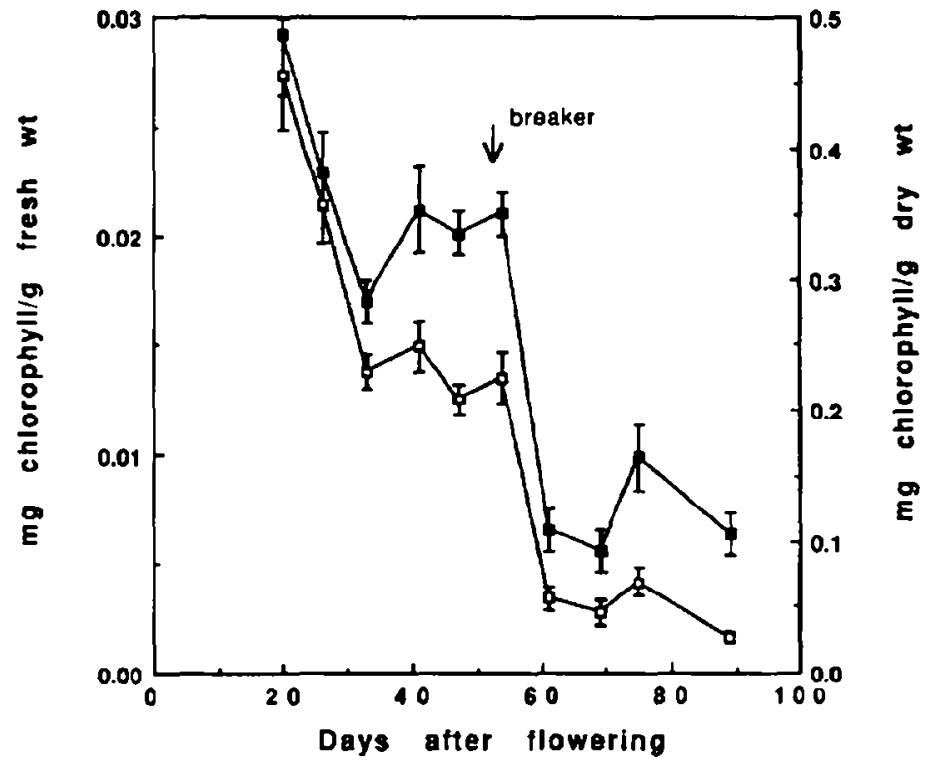

Fig. 3. Fresh ( $\square$ ) and dry weight (U) chlorophyll content of New Mexican type chile fruit harvested at weekly intervals throughout the season. The arrow indicates the approximate start of color change from green to red (breaker). Twelve fruit were tested at cach harvest date with six disks taken from each fruit. Error bars represent the $S E$ of the mean. The $L S D_{005,}$ values for the fresh and dry weight chlorophyll contents were 0.049 and 0.064 , respectively.

Table 1. Color and physiological changes in chile peppers harvested at four stages of maturity.

\begin{tabular}{|c|c|c|c|c|c|c|}
\hline $\begin{array}{l}\text { Ripeness } \\
\text { class' }\end{array}$ & $\begin{array}{l}\text { Color } \\
\text { (L) }\end{array}$ & $\begin{array}{l}\text { Color } \\
(\mathrm{a} / \mathrm{b})\end{array}$ & $\begin{array}{c}\text { Chlorophyll } \\
\text { (mg. } \mathrm{mg}^{-1} \text { fresh wt) }\end{array}$ & $\begin{array}{c}\text { Ethylene } \\
\left(\mu \mathrm{l} \cdot \mathrm{kg}^{-1} \cdot \mathrm{h}^{1}\right)\end{array}$ & $\frac{\mathrm{CO}_{2}}{\left(\mathrm{ml}^{\prime} \cdot \mathrm{kg}^{-1} \cdot \mathrm{h}^{\prime}\right)}$ & $\begin{array}{l}\text { B-galactosidase } \\
\left(\mathrm{mmol} \cdot \mathrm{mg}^{-1} \cdot \mathrm{h}^{-1}\right)^{y}\end{array}$ \\
\hline$\overline{\text { Green }}$ & 42.43 & -0.65 & $28.0 \mathrm{a}^{x}$ & $0.15 \mathrm{~b}$ & $79.75 \mathrm{a}$ & $9.3 \mathrm{c}$ \\
\hline Green/red & 40.11 & -0.34 & $22.12 \mathrm{ab}$ & $0.12 \mathrm{~b}$ & $78.5 \mathrm{a}$ & $17.9 \mathrm{bc}$ \\
\hline Red/green & 35.93 & 0.72 & $21.3 \mathrm{ab}$ & $0.13 \mathrm{~b}$ & $73.4 \mathrm{ab}$ & $45.5 \mathrm{a}$ \\
\hline Red & 35.47 & 2.09 & $16.6 \mathrm{~b}$ & $0.27 \mathrm{a}$ & $63.9 \mathrm{~b}$ & $29.1 \mathrm{~b}$ \\
\hline
\end{tabular}

${ }^{7}$ The color of the fruits in the ripeness classes were: green $=100 \%$ green, green/red $=10 \%$ to $20 \%$ red, red $/$ green $=50 \% 10 \quad \overline{60 \%}$ red, and red $=100 \%$ red.

${ }^{y} \mathrm{mmol}$ p-nitrophenyl/mg protein/h

${ }^{x}$ Mean separation within columns according to Fisher's ISD $(P \leq 0.05)$.

phyll corresponded to changes in the Land a/b color values (Table 1); as chlorophyll content decreased. a : b ratios increased, and $\mathrm{L}$ values decreased.

Carbon dioxide production decreased seasonally from 174 to $24.4 \mathrm{ml} \cdot \mathrm{kg}^{-1} \cdot \mathrm{h}^{-1}$ (Fig. 4). There was no climacteric rise of $\mathrm{CO}_{2}$ at the time of color change. The difference in respiration rate also was observed among the fruit harvested on the same day, but of different color (Table 1). Green peppers harvested 63 DAF had significantly higher rates of $\mathrm{CO}_{2}$ production than red peppers harvested the same day. In contrast, the highest peak of $\mathrm{C}_{2} \mathrm{H}_{4}$ production $\left(0.20 \mu \mathrm{l} \cdot \mathrm{kg}^{-1} \cdot \mathrm{h}^{-1}\right)$ was at $69 \mathrm{DAF}$ (Fig. 4), when the fruit were completely red but still succulent. A smaller $\mathrm{C}_{2} \mathrm{H}_{4}$ peak corresponded to the rapid weight and volume gains observed at 33 DAF. Also, red peppers showed significantly higher levels of $\mathrm{C}_{2} \mathrm{H}_{4}$ production than the other maturity groups (Table 1) harvested on the same day.

Cellulase and polygalacturonase activity were not detected using the DNS assay. B-galactosidase specific activity increased 7fold (54 to $69 \mathrm{DAF}$ ) when compared to the early harvests (20 to 47 DAF) (Fig. 5). Results were similar when expressed on a fresh weight basis. B-galactosidase activity remained higher in the red than in the green fruit until dehydration was evident (103 DAF). Fruit from the $R / G$ and $R$ maturity groups harvested on the same day had higher B-galactosidase activity than the $\mathrm{G} / \mathrm{R}$ or $\mathrm{G}$ groups (Table 1 ).

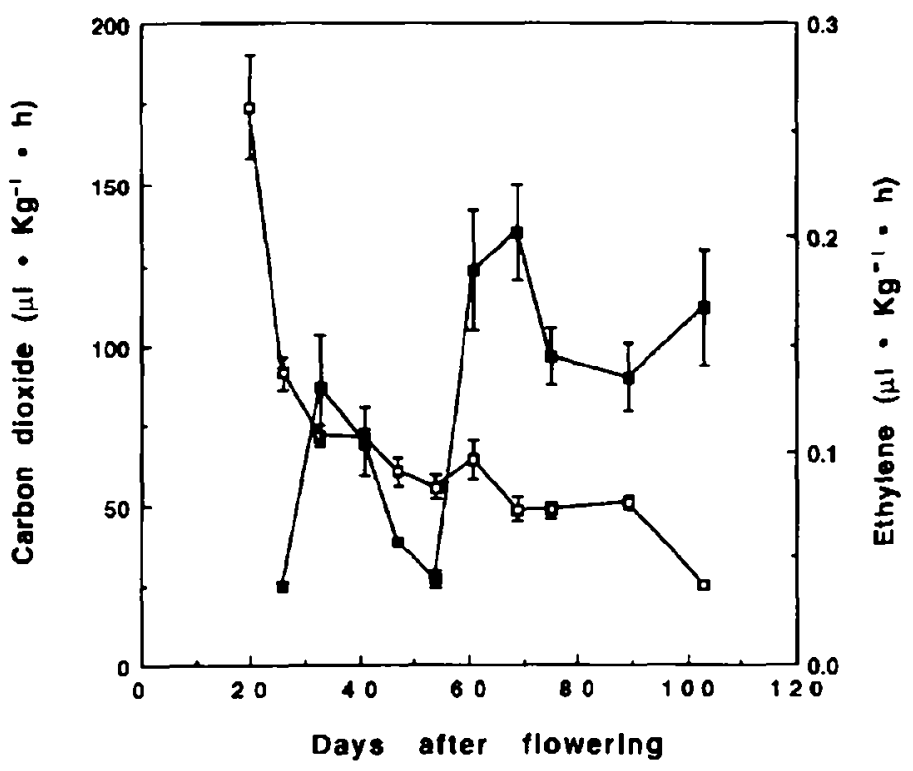

Fig.4. Carbon dioxide $(\square)$ and ethylene ( $\square$ )evolution of New Mexicantype chile peppers harvested at weekly intervals throughout the season. Four replications of three fruit each were used for each measurement. Error bars represent the SF, of the mean. The $\mathrm{LSO}_{(0, \ldots)}$ values for $\mathrm{CO}_{2}$ and ethylene data were 17.5 and 0.098 , respectively. 


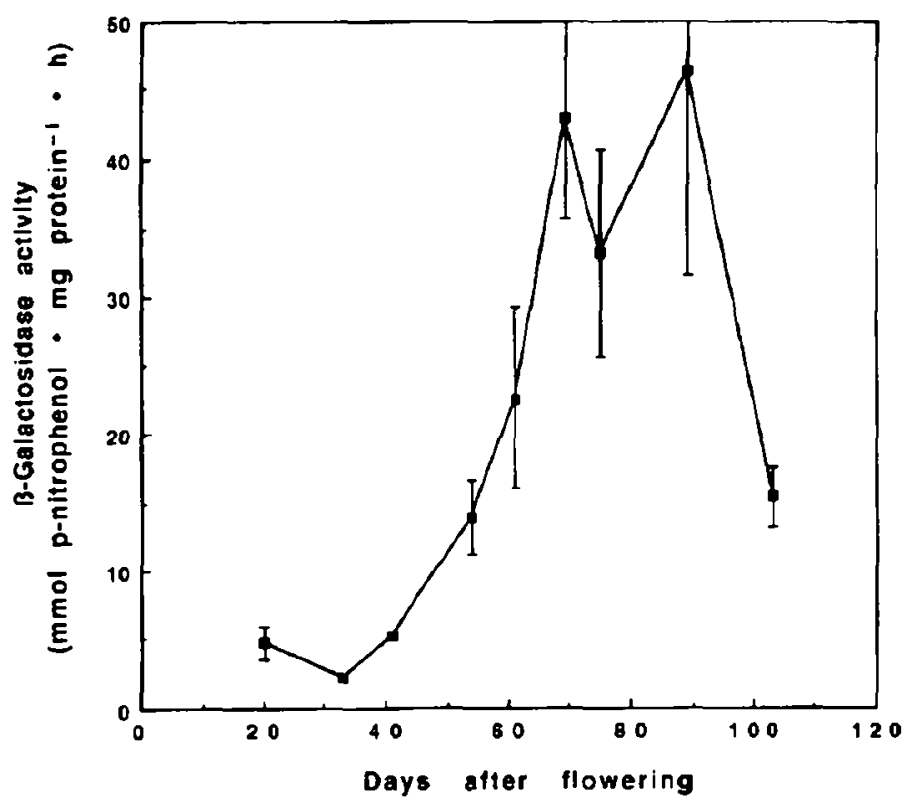

Fig. 5. B-galactosidase activity of New Mexican type peppers at each harvest date through the season. Error bars represent the $S E$ of the mean. The $1 . \mathrm{SD}_{(0.0)}$ for the $B$ galactosidase data was 2.71 .

SDS-PAGE separation of total proteins revealed increased protein band intensities at 27,35 , and $40 \mathrm{kDa}$ and decreased band intensity at $51 \mathrm{kDa}$ during the season (Fig. 6A). The same bands increased in intensity with maturity of fruit in proteins from fruit harvested on the same day (Fig. 6B).

\section{Discussion}

New Mexican type peppers were harvested weekly and analyzed for physiological changes related to the maturation and ripening of the fruit. Chile peppers from the first harvest (20 DAF) were noticeably small and undeveloped. Fruit weight and volume increased rapidly in the early harvests from 20 to 33 DAF, and reached a plateau at $40 \mathrm{DAF}$, when peppers were fully developed and mature-green. Peppers harvested $69 \mathrm{DAF}$ were firm, red, and succulent. At $75 \mathrm{DAF}$, fruit weight and volume began to decrease as fruit started to desiccate on the plant, a characteristic of the New Mexican type pepper. As fresh weight decreased, fruit firmness also decreased. In bell pepper fruit, weight loss correlated highly with decreased firmness and lower water potential (Lurie et al., 1986). They also found that fruit water potential at harvest was higher for green than red peppers, and firmness decreased as the color change advanced.

Chile pepper respiration rates were highest in immature, green pods and continued to decrease as maturation and ripening proceeded throughout the season. Typically, fruit harvested during an active growth phase have high respiration rates that generally decline as the fruit mature (Kader, 1987). Climacteric-type fruit show a unique ripening pattern, with a burst of respiratory activity and $\mathrm{C}_{2} \mathrm{H}_{4}$ production coincident with ripening (Biale, 1964). No respiratory climacteric was observed as chile peppers developed and ripened over the season. However, a $\mathrm{CO}_{2}$ increase may have occurred between the weekly sampling intervals and, therefore, was not observed. Also, aclimacteric increase in chile peppers may not be evident in freshly harvested fruit. In studies with 'Honey Dew' melons ( Cucumis melo L.), Pratt et al. (1977) found that fullsize melons held in storage exhibited a respiratory climacteric, whereas Miccolis and Salveit (1991) did not observe aclimacteric rise for 'Honey Dew' fruit harvested from the field and measured $5 \mathrm{~h}$ later. They postulated that the climacteric increase may not occur in freshly harvested melons when compared to stored fruit. Our classification of chile peppers as nonclimacteric agrees with postharvest studies of bell peppers (Lurie et al., 1986; Salveit, 1977) and 'Changjiao' hot peppers (Lu et al., 1990), which also have a nonclimacteric ripening pattern.

Ethylene production increased $\approx 5$-fold as chile fruit matured and ripened throughout the growing season. A large rise occurred when fruits were harvested $61 \mathrm{DAF}$, with a peak at $69 \mathrm{DAF}$. Coincident with peak $\mathrm{C}_{2} \mathrm{H}_{4}$ production, fruit firmness decreased, B-

A

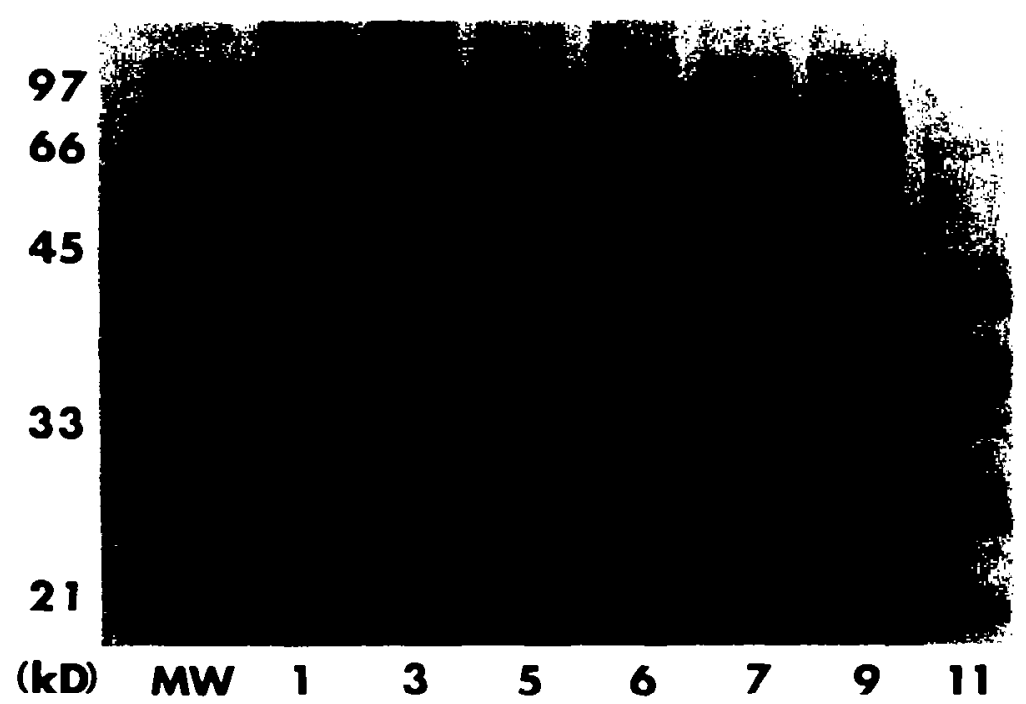

$\mathbf{B}$

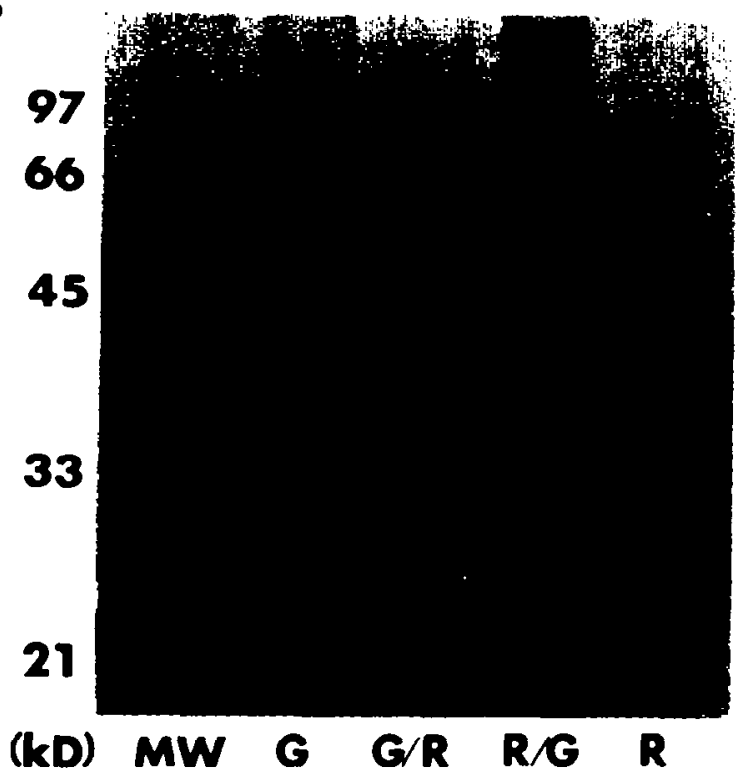

Fig. 6. Denatured protein patterns of New Mexican type peppers harvested throughout the growing season (A) and harvested on the same day (B). The numbers 1 to 11 at the bottom of gel A correspond to peppers harvested 20,33,47, 54,61, 75, and 103 days after flowering, respectively. Abbreviations at the bottom of gel B represent fruit maturity groups: $\mathrm{G}=100 \%$ green, $\mathrm{G} / \mathrm{R}=10 \%$ to $20 \%$ red, $\mathrm{R} / \mathrm{G}=50 \%$ to $60 \%$ red, and $\mathrm{R}=1(0) \%$ red. BioRad low molecular weight standards were 10 aded in the far left lane on each gel. 
galactosidase activity increased, and fruit changed from green to red. A smaller $\mathrm{C}_{2} \mathrm{H}_{4}$ peak at 33 DAF corresponded with the rapid growth and expansion of young pods. When chile from different maturity groups were harvested on the same day (Table 1), $\mathrm{C}_{2} \mathrm{H}_{4}$ production for $100 \%$ red fruit was twice as high as that for mature green fruit. Bell peppers responded similarly; $\mathrm{C}_{2} \mathrm{H}_{4}$ increased 2fold as mature green peppers ripened and turned red (Lurie et al., 1986; Salveit, 1977).

The peak $\mathrm{C}_{2} \mathrm{H}_{4}$ level for chile peppers was $0.27 \mu \mathrm{l} \cdot \mathrm{kg}^{-1} \cdot \mathrm{h}^{-1}$, compared to $0.70 \mu \mathrm{l} \cdot \mathrm{kg}^{-1} \cdot \mathrm{h}^{-1}$ for 'Chooreahong' hot peppers (Gross et al., 1986). In general, the $\mathrm{C}_{2} \mathrm{H}_{4}$ rates for peppers are low $(0.1$ to $1.0 \mathrm{ul} \cdot \mathrm{kg}^{-1} \cdot \mathrm{h}^{-1}$ ) when contrasted with tomatoes (Lycopersicon esculentum Mill.), which may reach $\mathrm{C}_{2} \mathrm{H}_{4}$ production rates of 10 $\mu \mathrm{l} \cdot \mathrm{kg}^{-1} \cdot \mathrm{h}^{-1}$ at the climacteric peak (Biale, 1964). Ethylene generally has been accepted as the natural ripening hormone based on physiological evidence. Recently, molecular inactivation of $\mathrm{C}_{2} \mathrm{H}_{4}$ biosynthesis has shown conclusively that ethylene controls tomato fruit ripening and many of the biochemical changes associated with it (Oeller, 1991). Although peppers are classified as nonclimacteric, $\mathrm{C}_{2} \mathrm{H}_{4}$ is synthesized at levels sufficient to induce ripening. However, unlike tomatoes, a respiratory rise does not indicate the onset of ripening, and the loss of green pigmentation and ripening may proceed more slowly.

In addition to changes in respiration and $\mathrm{C}_{2} \mathrm{H}_{4}$ production, the fruit ripening process often involves changes inenzymatic activity related to cell wall degradation. Whereas ripening tomatoes show increased levels of PG and cellulase activity (Babbitt et al., 1973), PG and cellulase were undetected for chile peppers under the assay conditions described. ß-galactosidase specific activity increased 7-fold in ripening chile peppers, similar to that reported for 'Chooraehong' hot peppers, in which total $\beta$-galactosidase activity increased 15-fold, and PG was undetected (Gross et al., 1986).

The exact role of $\beta$-galactosidase is unknown, but the loss of galactose residues from cell walls may be a result of this enzyme (Gross and Sams, 1984; Presey, 1983). B-galactosidase was found to degrade apple galactans and increase as apples matured (Bartley, 1974). Pressey (1983) found three B-galactosidase isozymes in tomato and one of the isozymes hydrolyzed tomato galactan. $\beta$ galactosidase was found at high levels in the tomato, and the hydrolytic isozyme increased during fruit ripening. The loss of galactose and arabinose containing cell wall polysaccharides has been associated with fruit ripening in several species (Gross and Sams, 1984). Galactose was the major residue lost in seven species, among them peppers (bell and hot). Thus, the dramatic increase in $B$-galactosidase activity as chile peppers ripened would be expected.

Distinct protein changes were found between harvest dates (Fig. 6A) and among maturity groups (Fig. 6B), including decreased intensity of a $51-\mathrm{kDa}$ protein. A $40-\mathrm{kDa}$ band appeared to increase in intensity as the fruit turned red. At $47 \mathrm{DAF}$, a $35 \mathrm{kDa}$ protein band increased suddenly. The appearance of this band precedes fruit color change from green to red, decreased firmness (Fig. 2), chlorophyll loss (Fig. 3). and $\mathrm{C}_{2} \mathrm{H}_{4}$ increase (Fig. 4). and correlates closely with the beginning of Increased B-galactosidase activity (Fig. 5). Pressey (1983) found three ß-galactosidase isozymes in tomato, and one of the isozymes hydrolyzed tomato galactan and increased with fruit ripening. The molecular weight of the three isoforms were found to be 144,000 (1). 62,000 (II), and 71,000 (III) using column chromatography. Proteins increasing with pepper maturity in this study were smaller than $71 \mathrm{kDa}$; however, denaturation may have affected the original conformation.

Characterization of $\beta$-galactosidase in peppers has been lim- ited. Gross et al. (1986) reported the presence of at least four isozymes in hot peppers. Preliminary investigations using a MonoS chromatography column (Pharmacia, Piscataway, N.J.) has also shown the presence of four isozymes in New Mexican type peppers (Biles, Wall, and Kuehn, unpublished). Further work is needed in purifying pepper 3 -galactosidase and the 40-, 35-, and 27-kDa proteins to understand their function.

In conclusion. New Mexican type chile peppers appear to be nonclimacteric, although a rapid increase of $\mathrm{C}_{2} \mathrm{H}_{4}$ corresponds with color change. Corresponding with the rise in $\mathrm{C}_{2} \mathrm{H}_{4}$ is a sudden loss of chlorophyll, decrease in firmness, an increase of ß-galactosidase activity, and the appearance of a new protein band at $35 \mathrm{kDa}$. These characteristics require further investigation to determine their role in chile pepper development and ripening. Manipulation of these variables may ultimately lead to enhanced quality and extension of shelf life.

\section{Literature Cited}

Abeles, F.B., L.J. Dunn, and W.L. Hershberger. 1989. Hormonal regulation, and the intracellular localization of a $33-\mathrm{kDa}$ cationic peroxidase in excised cucumber cotyledons. Plant Physiol. 89:664-668.

Abeles, F.B. and C.L. Biles, 1990. Cellulase activity in developing apple fruits. Scientia Hort. 47:77-87.

Babbitt, J.K., M.J. Powers, and M.E. Patterson. 1973. Effects ofgrowth-regulators on cellulase, polygalacturonase, respiration, color, and texture of ripening tomatoes. J. Amer. Soc. Hort. Sci. 98:77-81.

Bartley, I.M. 1974. ß-galactosidase activity in ripening apples. Phytochemistry 13:2107-2111.

Biale, J.B. 1964. Growth, maturation, and senescence in fruit. Science 146:880888 .

Bosland, P.W., A.L. Bailey, and J. Iglesias-Olivas. 1988. Capsicum pepper varieties and classification. New Mexico Coop. Ext. Circ. 530.

Gross, K.C. and C.E. Sams. 1984. Changes in cell wall neutral sugar composition during fruit ripening: A species survey. Phytochemistry 23:2457-2461.

Gross, K.C., A.E. Watada, S.D. Kang, S.D. Kim, and S.W. Lee. 1986. Biochemical changes associated with the ripening of hot pepper fruit. Physiol. Plant. 66:3136.

Kader, A.A. 1987. Respiration and gas exchange of vegetables, p. 25-44. In: J. Weichmann (ed.). Postharvest physiology of vegetables. Marcel Dekker. New York.

Laemmli, U.K. 1970. Cleavage of structural proteins during the assembly of the head of bacteriophage T4. Nature 227:680-685.

Lu, G., C. Yang, H. Liang, and Z. Lu. 1990. 'Changjiao' hot peppers are nonclimacteric. HortScicnce 25:807.

Lurie, S., B. Shapiro, and S. Ben-Yehoshua. 1986. Effects of water stress and degree of ripeness on rate of senescence of harvested bell pepper fruit. J. Amer. Soc. Hort. Sci. 111:880-885.

Miccolis, V. and M.E. Saltveit. 1991. Morphological and physiological changes during fruit growth and maturation of seven melon cultivars. J. Amer. Soc. Hort. Sci. 116:1025-1029.

Miller, C.H., R.E. McCollum, and S. Claimon. 1979. Relationship between growth of bell peppers ( Capsicum annuum L.) and nutrient accumulation during ontogeny in field environments. J. Amer. Soc. Hort. Sci. 104:852-857.

Miller, G.L. 1959. Use of dinitrosalicylic acid reagent for determination of reducing sugar. Anal. Chem. 31:426-428.

Neuhoff, V., N. Arnold. D. Taube, and W. Ehrhardt. 1988. Improved staining of proteins in polyactylamide gels including isoelectric focusing gels with clear background at nanogram sensitivity using coomassie brilliant blue G-250. Electrophoresis 9:255-262.

Oeller, P.W., L. Mitt-Wong, L.P. Taylor, D.A. Pike, and A. Theologis. 1991. Reversible inhibition of tomato fruit senescence by antisense RNA. Science 254:437-439).

Pety, E. and D.J. Cotter. 1984. Growth of long green chile pepper fruit ( Capsicum annuиm L.). New Mexico Agr. Expt. Sta. Res. Rpt. 556.

Pratt, H.K., J.D. Goeschl, and F.W. Martin. 1977. Fruit growth and development, ripening and the role of ethylene in the Honey Dew muskmelon. J. Amer. Soc. Hort. Sci. 102:203-210.

Pressey, R. 1983. ß-galactosidases in ripening tomatoes. Plant Physiol. 71:132 135.

Salveit, M.E. 1977. Carbon dioxide, ethylene and color development in ripening mature green bell peppers. J. Amer. Soc. Hort. Sci. 102:523-525. 